\title{
Correction to: Microbial diversity of saline environments: searching for cytotoxic activities
}

Carolina Díaz-Cárdenas ${ }^{1}$, Angela Cantillo², Laura Yinneth Rojas³ ${ }^{3}$, Tito Sandoval ${ }^{3}$, Susana Fiorentino ${ }^{3}$, Jorge Robles ${ }^{4}$, Freddy A. Ramos ${ }^{5}$, María Mercedes Zambrano ${ }^{2}$ and Sandra Baena ${ }^{1 *}$ (1)

\section{Correction to: AMB Expr (2017) 7:223} https://doi.org/10.1186/s13568-017-0527-6

The original version of this article (Diaz-Cardenas et al. 2017) unfortunately contained a mistake in Fig. 1. The pie chart of Fig. 1 should explain the distribution of the relative abundance of the Bacteria and Archaea strains isolated at Zipaquirá salt mine: Proteobacteria 39\%; Actinobacteria 9\%, Bacteroidetes 1\%, Archaea 3\% and Firmicutes $48 \%$ instead of NOMBRE DE CATEGORIA [PORCENTAJE]. The corrected Fig. 1 and caption are given in this erratum.

The original article has been corrected.

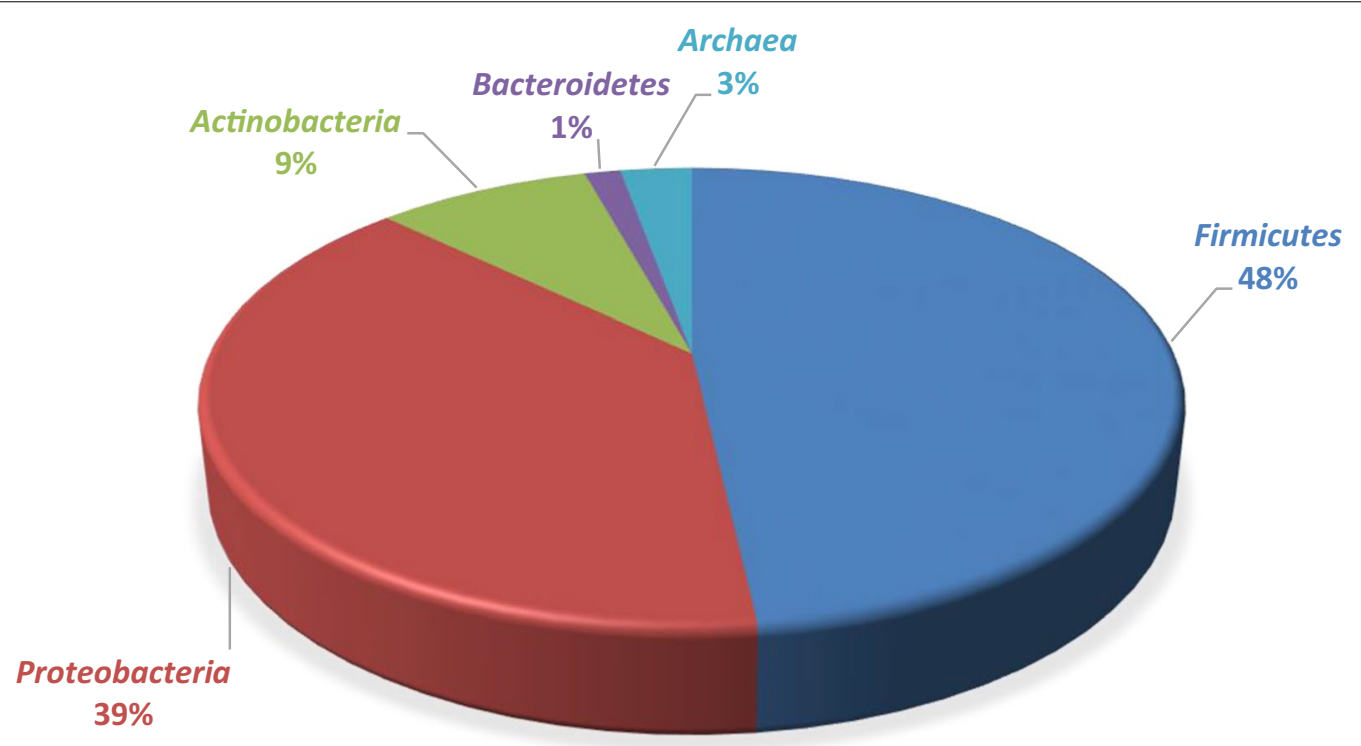

Fig. 1 Distribution of the relative abundance of the Bacteria and Archaea strains isolated at Zipaquirá salt mine

\footnotetext{
*Correspondence: baena@javeriana.edu.co

${ }^{1}$ Unidad de Saneamiento y Biotecnología Ambiental, Departamento

de Biología, Pontificia Universidad Javeriana, POB 56710, Bogotá DC,

Colombia

Full list of author information is available at the end of the article
} provided you give appropriate credit to the original author(s) and the source, provide a link to the Creative Commons license, and indicate if changes were made. 


\section{Author details}

1 Unidad de Saneamiento y Biotecnología Ambiental, Departamento de Biología, Pontificia Universidad Javeriana, POB 56710, Bogotá DC, Colombia. ${ }^{2}$ Corporación Corpogen, Carrera 5 \# 66A-34, Bogotá DC, Colombia. ${ }^{3}$ Grupo de Inmunobiología y Unidad de Investigación en Ciencias Biomédicas, Pontificia Universidad Javeriana, POB 56710, Bogotá DC, Colombia. ${ }^{4}$ Grupo de Investigación Fitoquímica, Pontificia Universidad Javeriana, POB 56710, Bogotá DC Colombia. ${ }^{5}$ Departamento de Química, Universidad Nacional de ColombiaSede Bogotá, Carrera 30 \# 45-03, Bogotá DC, Colombia.

The original article can be found online at https://doi.org/10.1186/ s13568-017-0527-6.

\section{Publisher's Note}

Springer Nature remains neutral with regard to jurisdictional claims in published maps and institutional affiliations.
Received: 20 February 2018 Accepted: 20 February 2018

Published online: 09 March 2018

\section{Reference}

Díaz-Cárdenas C, Cantillo A, Rojas LY, Sandoval T, Fiorentino S, Robles J, Ramos FA, Zambrano MM, Baena S (2017) Microbial diversity of saline environments: searching for cytotoxic activities. AMB Expr 7:223. https://doi. org/10.1186/s13568-017-0527-6 